\title{
ILLEGAL MIGRATION THROUGH THE PRACTICE OF THE COURT OF JUSTICE OF THE EUROPEAN UNION AND THE CONSEQUENCES FOR THE REPUBLIC OF CROATIA
}

\author{
Marina Čepo, , LLM, PhD candidate \\ Josip Juraj Strossmayer University of Osijek, Academy of Arts Osijek \\ Kralja Petra Svačića 1/f, Osijek, Croatia \\ mcepo@uaos.hr
}

\begin{abstract}
The European humanitarian and migration crisis created by the mass influx of migrants into the European Union that began in 2015 opened up many issues and areas that have not been systematically discussed. The area of irregular entry is certainly one of the most important, precisely because of the legal gaps in the application of the Dublin III Regulation. Recently, the question of irregular entry came before the Court of Justice of the European Union (CJEU) in two cases brought by Slovenia and Austria, whose outcomes have significant consequences for the Republic of Croatia. In the Court's opinion, admission of third-country nationals in the Member State, with the intention of transferring to another Member State to seek international protection, is considered irregular entry, even in emergencies such as the mass influx of migrants to the state border. Member States receiving a third-country national on their territory shall ensure that all conditions for legitimate entry are met. Without legal preconditions for entry, legitimate residence on the territory of the country of first entry or legitimate transit to another Member State is not possible. The passage of third-country nationals from the Republic of Croatia for humanitarian reasons has resulted in irregular migration because requirements for entry into the state territory were not met. Within these judgments, the CJEU has discussed issues relating to the presumption of lawful entry into the territory of the European Union and the issue of the treatment of a Member State in which a third-country national has first entered. The importance of the CJEU decision is in the fact that it clarifies that the mechanism established by the Dublin III Regulation must inevitably apply, even in exceptional circumstances.

The established form of action will certainly be of great importance in the further treatment of Member States because the inflow of migrants to the external borders of the European Union is still expected. This paper will analyse the legal framework regulating the issue of irregular entry and the protection of external borders of the European Union and the main arguments of the CJEU, as well as the opinion of the Advocate General, which was opposing the opinion of the CJEU. The impact of such a Court decision will be critically analysed in this paper as well.
\end{abstract}

Keywords: migration crisis, irregular entry, visa, transit, international protection, thirdcountry nationals 


\section{INTRODUCTION}

Migration has been a common and everyday occurrence all throughout history and remains so until the present. All the countries in the world, including Member States of the European Union (hereinafter 'the EU'), should be prepared to address it. The migration and refugee crisis which, as a result of the Arab Spring, shook the EU in 2015, reflected all the shortcomings of the Common European Asylum System (hereinafter 'the CEAS') and the migration policy of the EU. One of the problems which proved to be crucial from the very beginning is the issue of irregular entry. For the purpose of this paper, it is important to note the differentiation between refugees and migrants. This is relevant not only to provide a clearer understanding of the subject, but also given the fact that migrants and refugees do not enjoy the same rights, do not qualify for the same level of international protection and are subject to different procedures and regulations. This paper focuses on the period from September 2015 to March 2016 (hereinafter 'the crisis period'), when the refugee crisis reached its culmination point, showing the most important problems and shortcomings of the CEAS. ${ }^{1}$ This paper discusses two research questions which have been raised during the migration and refugee crisis period in the EU. The first question concerns the admission of third-country nationals who do not meet the entry requirements into the territory of a border Member State for the purpose of transit to another EU Member State. Is the admission of third-country nationals, in exceptional circumstances such as the mass influx of migrants and refugees, for the purpose of transit to another Member State, considered irregular or regular entry? The second question relates to the admission of third-country nationals who do not meet the entry requirements into the territory of a Member State on humanitarian grounds. Specifically, is the entry of third-country nationals into the territory of a border Member State authorised on humanitarian grounds considered regular entry? The Court's judgments in cases A.S. v. Slovenia ${ }^{2}$ and Khadija Jafari and Zainab Jafari v. Bundesamt für Fremdenwesen und $A s y B$ are significant for answering these research questions. The opinion of the Advocate General contradicted the Court's decision, making the discussion even more relevant. By its judgments the Court managed, once again, to protect the integrity of the EU and attempted to strengthen the Dublin system and the common European policy on asylum. However, the effects and the significance of the judgments will have a considerable impact on the future. The judgments also

See further: Lalić, G., Razvoj zajedničkog europskog sustava azila, Hrvatska i komparativna javna uprava: časopis za teoriju i praksu javne uprave, vol. 7 No. 4, 2007

2 Case c-490/16 A. S. vs. Republic of Slovenia (2017) ECL I 585

3 Case C-646/16 Khadija Jafari and Zainab Jafari vs. Bundesamt für Fremdenwesen und Asyl (2017) ECL I 586 
raise the question of whether the Court put the protection of human rights in an inferior position to policies implemented by the EU. The effect of the judgments in the cases concerned is relevant to the Republic of Croatia (hereinafter 'Croatia') as well since the country was a subject matter of the proceedings ${ }^{4}$. With a view to answering the research questions raised, the paper will analyse the obligations of the Member States as regards to international and European asylum law, the main arguments of the Court as well as the opinion of the Advocate General, which was opposing the opinion of the Court. For the purpose of this paper, an interview will be conducted with the heads of the Ministry of the Interior responsible for irregular migration and the border crossing point between Serbia and Croatia, at which the families in the cases concerned first entered EU territory in the crisis period.

\section{EU MEMBER STATES' OBLIGATIONS TOWARDS REFUGEES UNDER INTERNATIONAL AND EUROPEAN ASYLUM LAW}

The entire EU migration law involves the interaction of national laws, European law and international law. ${ }^{5}$ International and European law complement each other: the EU law brings general rights which are provided for on international level. When it comes to international human rights law, there are no generic rights related to the entry of third-country nationals ${ }^{6}$, whereas EU legislation ensures far more individual rights. In relation to refugees, the Member States' mandatory compliance with the Geneva Convention ${ }^{7}$ and human rights means prohibiting the infringement of international obligations when applying European law in the field of border control and visa issuance. Entry and border control must be pursued in compliance with human and refugee rights. ${ }^{8}$ As Hathaway ${ }^{9}$ finds, refugee rights are matters of international law to the extent that they derive from one of the accepted trio of international law sources, in this case the Geneva Convention, and they do not exist as an alternative to, or in competition with, general human

4 Croatia was not a party to the proceedings, but a subject matter thereof since the third-country nationals concerned first entered EU territory in Croatia

5 See further: Goldner Lang, I.: The European Union and Migration: An Interplay of National, Regional, and International Law, American journal of international law, 111, 2017, p. 509-513

6 See: Weissbrodt, D., The Human Rights of Non-citizens, (OUP 2008); and Mantouvalou, R., The Labour and Social Rights of Migrants in International Law, in: Rubio-Marin (ed.), Human Rights, 2014, p. $177-211$

7 Convention Relating to the Status of Refugees, 25 July 1951.as amended by the 1967 Protocol Relating to the Status of Refugees, 31 January 1967. (Geneva Convention)

8 Hailbronner/Thym, Legal Framework for Entry and Border Control, in Hailbronner, K.; Thym D., (eds.), EU Immigration and Asylum Law, A Commentary, 2nd edition, C.H.Beck/Hart/Nomos, 2016, p. 48-49

9 Hathaway, C., J., The evolution of the refugee rights regime, Cambridge University Press, 2005, p. 75-153 
rights. When we talk about the refugee crisis on EU territory during the crisis period, we talk about refugee rights. Although, as Schuster ${ }^{10}$ finds, very often refugees are being converted into irregular migrants in political and public discourse, and the current EU regime shields EU Member States from their international legal obligations. From Article 3 of the Convention for the Protection of $\mathrm{Hu}-$ man Rights and Fundamental Freedoms ${ }^{11}$ (hereinafter 'Convention on Human Rights') follows that non-refoulment stems from the absolute prohibition of torture. ${ }^{12}$ The Geneva Convention defines the term 'refugee'13 and prohibits punishment due to unlawful entry in the country where protection is claimed. The implications of stringent border controls, provided for in the Schengen Borders Code, can be particularly severe for persons seeking international protection. There are reasonable prospects that, in most cases, persons fleeing persecution, a serious threat to their life or physical or mental health or war will not be admissible to the Schengen area. In numerous cases, they will also not possess a valid travel document or other necessary documents. Irrespective of the non-compliance with entry requirements, every person must have the right to entry in order to seek international protection and their stay must be allowed during the examination of their application. ${ }^{14}$ The EU is not a signatory to the Geneva Convention, but the Member States are, each of them individually and only with regard to their own territory. The CEAS ${ }^{15}$ is based on the Dublin system composed of the Dublin III Regulation and the Regulation on the establishment of Eurodac for the comparison of fingerprints ${ }^{16}$. The Dublin system is based on the principles of solidarity and fair sharing of responsibilities among Member States ${ }^{17}$, laid down in the

10 Schuster, L., Turning refugees into 'illegal migrants': Afghan asylum seekers in Europe, Ethnic and Racial Studies, vol. 34, - Issue 8: Irregular Migrants: Policy, Politics, Motives and Everyday Lives, 2011, p. 1392-1407

11 Adopted in Rome on 4 November 1950, Narodne novine (Official Gazette) - International treaties, No. 18/97, 6/99 - consolidated text, 8/99 - corr., 14/02, as amended by Protocol 14 to the Convention (2010) Narodne novine - International treaties, No. 1/06

12 See Soering vs. United Kingdom (1989) ECHR 14

13 Geneva Convention, Article 1(a)

14 Egbuna-Joss, E., op. cit. note, p. 60-62

15 See more in: Lalić, G., Razvoj zajedničkog europskog sustava azila, Hrvatska i komparativna javna uprava: časopis za teoriju i praksu javne uprave, vol. 7 No. 4, 2007

16 Regulation (EU) No 603/2013 of the European Parliament and of the Council of 26 June 2013 on the establishment of Eurodac for the comparison of fingerprints for the effective application of Regulation (EU) No 604/2013 establishing the criteria and mechanisms for determining the Member State responsible for examining an application for international protection lodged in one of the Member States by a third-country national or a stateless person and on requests for the comparison with Eurodac data by Member States' law enforcement authorities and Europol for law enforcement purposes, and amending Regulation (EU) No 1077/2011 establishing a European Agency for the operational management of large-scale IT systems in the area of freedom, security and justice (2013) SL L180

17 Goldner Lang, I., op. cit. note 5, p. 512 
Treaty of the Functioning of the European Union ${ }^{18}$ (hereinafter 'TFEU'), which ensure the efficiency of the system. It is precisely the lack of solidarity among the Member States that led to the biggest problems the Dublin system faced in the crisis period. Goldner Lang points out that there is a problematic relationship between the Dublin state-of-first-entry rule and the application of the principle of solidarity, which results in fair responsibility-sharing between the Member States. She also points to the problem stemming from the principle of solidarity in terms of shifting the burden instead of sharing it. ${ }^{19}$ Article 3 of the Directive on common standards and procedures in Member States for returning irregularly staying third-country nationals ${ }^{20}$, defines irregular stay, whereas Article 5 of the Schengen Borders Code lays down the conditions for entry. Exceptions from conditions for entry shall be granted, inter alia, on humanitarian grounds or because of international obligations. ${ }^{21}$ This means that a Member State can apply a more favourable legal interpretation for the refugees, however, only with regard to its own territory, without affecting other Member States. If a Member State does not apply the Geneva Convention to third-country nationals who meet the requirements for refugee status directly, it has to apply the European protection mechanism. It also has to make sure that the conditions for a lawful entry are fully met, which follows from the judgments in cases A.S. v. Slovenia and Jafari v. Bundesamt fur Fremdenwesen und Asyl.

\section{IRREGULAR ENTRY THROUGH THE PRACTICE OF THE COURT OF JUSTICE}

Even though there are wide international and European legal frameworks regulating irregular migration, their interweaving and application in the refugee crisis period led to numerous discussions and opened up legal matters which have not been discussed before. The paper will proceed with a presentation of the most prominent issues relating to irregular entry in the case-law of the Court. These

18 Consolidated versions of the Treaty on European Union and the Treaty on the Functioning of the European Union Consolidated version of the Treaty on European Union Consolidated version of the Treaty on the Functioning of the European Union Protocols Annexes to the Treaty on the Functioning of the European Union Declarations annexed to the Final Act of the Intergovernmental Conference which adopted the Treaty of Lisbon (2007) OJ C 202, Art. 80 (TFEU)

19 Goldner Lang, I., Ima li solidarnosti u azilu i migracijama u Europskoj uniji? Prvih deset godina razvoja sustava azila u Hrvatskoj, in: Župarić-Iljić, D., (ed.), Zagreb: Institut za migracije i narodnosti: Centar za mirovne studije: Kuća ljudskih prava, 2013, p. 33-45.

20 Directive 2008/115 (EC) of the European Parliament and of the Council of 16 December 2008 on common standards and procedures in Member States for returning illegally staying third-country nationals (2008) OJ L 348 (The Return Directive)

21 Schengen Borders Code, op. cit., note 2, Article 6(5)(c) 
issues proved to be crucial during the crisis period due to inconsistencies in their interpretation and the application of legal provisions. The aforementioned questions referred to the Court by the Supreme Court of the Republic of Slovenia and the Supreme Court of the Republic of Austria are very similar and concern the interpretation of the provisions of the Dublin III Regulation and the Schengen Borders Code. Both cases are related to the issue of irregular entry in the crisis period. In both cases, the Court's opinion was opposing the one of the Advocate General Eleanor Sharpston ${ }^{22}$ (hereinafter 'Advocate General'), opening up opportunities for examining the Court's view.

\subsection{CASE C-490/16 A.S. v. SLOVENIA - FACTUAL SITUATION}

Mr A.S., a Syrian national, travelled from Syria to Turkey and across a number of countries to finally arrive in Croatia. He was transferred by the Croatian authorities across Croatian territory to the Slovenian border. On 20 February $2016 \mathrm{Mr}$ A.S. entered Slovenia, where he was registered. On the following day, after an attempt to cross the Austrian border, he was sent back to the Slovenian authorities. After that event, Mr A.S. lodged an application for international protection in Slovenia. On that same day, Slovenia asked Croatia to take back 66 people of whom Mr A.S. was one. Croatia confirmed its acceptance that it was the Member State responsible under the Dublin III Regulation. After the Slovenian Ministry of the Interior informed $\mathrm{Mr}$ A.S. that his application for international protection would be examined by Croatia, as the Member State responsible, he challenged that decision before the Administrative Court. He stated that the Croatian State authorities' conduct must be interpreted as meaning that he entered Croatia lawfully. His request was rejected and Mr A.S. appealed against the first instance decision to the referring court seeking clarification from the Court on how the terms of irregular or unlawful entry are to be applied in this context. ${ }^{23}$ In this particular case, the Court had to decide if an applicant for international protection may, in an appeal against a decision to transfer him, plead incorrect application of the criterion for determining responsibility relating to the irregular crossing of a Member State's border. It also had to rule if the periods laid down in Article 13(1) and Article 29(2) of the Dublin III Regulation continue to run after an appeal has been lodged against the transfer decision concerned, including when the court hearing that appeal has decided to seek a preliminary ruling from the Court. In addition, the Court had to answer the following question: In the light of the fact that the

\footnotetext{
22 Opinion of Advocate General in cases C-490/16 and C-646/16 A.S. v. Republic of Slovenia and Jafari v. Bundesamt für Fremdenwesen und Asyl.,8 June 2017

23 The request for a preliminary ruling concerned the interpretation of Art. 13(1), Art. 27(1) and Art. 29(2) of the Dublin III Regulation
} 
entry of third-country nationals is tolerated by the authorities of the first Member State only for the purpose of transit to another Member State, must it be assumed that the entry is unlawful?

\subsection{CASE C-646/16 JAFARI v. BUNDESAMT FÜR FREMDENWESEN UND $A S Y L$-FACTUAL SITUATION}

Ms Khadija Jafari and Ms Zainab Jafari and their children are Afghan nationals, who entered EU territory in Greece, where they stayed for three days before leaving EU territory and re-entering in Croatia, which allowed them to travel through its territory. Upon entering the Austrian border, the Jafari families lodged an application for international protection. The Austrian authorities considered that Croatia is to be responsible for examining that application given the systemic flaws in the asylum procedure in Greece. The Jafari sisters contested this conclusion. They took the view that their entry was authorised on humanitarian grounds under the Schengen Borders Code and thus lawful, considering Austria to be the Member State responsible for examining their application. In its request for a preliminary ruling, the Upper Administrative Court in Vienna sought guidance for addressing the aforementioned legal issues. ${ }^{24}$ In this particular case, the Court had to answer the following questions: whether the Dublin III Regulation should be interpreted by reference to other EU acts; did the cooperation and facilities provided by the EU transit States amount to visas; how the phrase 'irregularly crossed the border' should be interpreted and whether third-country nationals who were allowed to enter the Schengen area during the humanitarian crisis fall within the exceptions to the normal rules in the Schengen Borders Code. Given the similarities between the proceedings, the Court decided to hold a joint hearing for these two cases.

\subsection{ADVOCATE GENERAL'S OPINION IN CASES A.S. v. SLOVENIA AND JAFARI v. BUNDESAMT FÜR FREMDENWESEN UND ASYL}

At the very beginning of her opinion, the Advocate General states that the Court is asked to provide a legal solution to fit the unprecedented factual circumstances of the refugee crisis. She takes the view that the Dublin III Regulation should be interpreted by reference to the wording, context and objectives of that Regulation alone, rather than in conjunction with other EU acts, like the Schengen Borders Code and the Return Directive. Apart from that, she considers that certain Member States allowed the persons concerned to cross the external border of the EU and subsequently to travel through to other Member States in order to lodge an

24 The request for a preliminary ruling concerned the interpretation of Arts 2, 12 and 13 of the Dublin III Regulation and Art. 5 of the Schengen Borders Code 
application for international protection, which does not equate to the issuance of a 'visa', since the rules governing the issuing of visas were not met in these cases. Furthermore, she considers that the words 'irregular crossing' in the Dublin III Regulation do not cover a situation where, as a result of a massive inflow of third-country nationals, Member States allow third-country nationals to cross the external border of the EU and subsequently travel through other EU Member States to lodge an application for international protection in a particular Member State. She concludes that, if the entry conditions ${ }^{25}$ are not met, the crossing of an external border by a third-country national must, in the formal sense, be considered 'irregular'. However, the entry of the person concerned is de facto allowed, the legal basis for the authorisation being the derogation ${ }^{26}$ under the Schengen Borders Code. Given the fact that Mr A.S. and the Jafari families first entered EU territory in Greece and then temporarily left it to eventually reenter in Croatia, the Advocate General finds that Croatia is the country of second entry and not bound by the Dublin III Regulation, irrespective of the fact that the persons concerned could not reenter Greece due to a previous decision of the Court. ${ }^{27}$ She reiterates the unprecedented inflow of persons into the Western Balkans and the fact that no bespoke criterion was inserted into the Dublin III Regulation to cover that situation. She agrees with the Italian government's argument that according to Article 78(1) of the TFEU, it is correct to consider Articles 31 and 33 of the Geneva Convention the starting point for interpreting Article 13(1) of the Dublin III Regulation. Therefore, the states allowing transit through their territory acted in accordance with their obligations under the Geneva Convention given the fact that the crisis period involved refugees. This fact is important and must not be neglected. She also states that the right to asylum laid down in Article 18 of the Charter of Fundamental Rights of the $\mathrm{EU}^{28}$ and the prohibition of torture or inhuman or degrading treatment, which the third-country nationals would have been subject to if they had stayed in the unresolved situation at the national borders, should be taken into consideration. If the national asylum system of a particular Member State is overloaded, it is impossible to guarantee effective access to the procedures granting international protection, thereby compromising the objective of rapid processing of applications for international protection laid down in the Directive on common procedures for granting and withdrawing international protection. ${ }^{29}$ That being said, the Advocate General concludes that

\footnotetext{
25 Schengen Borders Code, op. cit., Article 5(1)

$26 \quad$ Ibid. Article 5(4)(c)

27 See: infra, note No. 37, 38 and 39, p 8

28 Charter of Fundamental Rights of the European Union (2007) OJ C 303

29 Directive 2013/32/EU of the European Parliament and of the Council of 26 June 2013 on common procedures for granting and withdrawing international protection (2013) OJ L 180
} 
Slovenia is the Member State responsible for examining Mr A.S.'s application for international protection and that Austria is the Member State responsible for examining the Jafari families' applications.

\subsection{THE JUDGMENT OF THE COURT AND THE UNDERLYING LEGAL FRAMEWORK}

The Court takes the view that an applicant for international protection is entitled, in an appeal against a decision to transfer him, to plead incorrect application of the criterion for determining responsibility relating to the irregular crossing of the border of a Member State. ${ }^{30}$ Referring to the judgment in case Ghazelbash ${ }^{31}$, the Court decides that an applicant for international protection may, in an appeal against a decision to transfer him, plead incorrect application of the criterion for determining responsibility relating to the irregular crossing of a Member State's border. It also states that the lodging of an appeal against a transfer decision has no effect on the running of the period laid down in the Dublin III Regulation. Furthermore, it considers that the entry of a third-country national, even if tolerated and facilitated by the authorities of a Member State, must be regarded as irregular. Regarding derogation from the Schengen Borders Code on humanitarian grounds, the Court reiterates that such authorisation is only valid for the territory of the Member State in question and not for the territories of other Member States. ${ }^{32}$ In addition, if it were accepted that the entry of a third-country national authorised by a Member State on humanitarian grounds does not constitute an irregular crossing of the border, that would imply that the Member State in question is not responsible for examining the application for international protection lodged by that person in another Member State. Such a conclusion would, however, be incompatible with the general structure and objectives of the Dublin III Regulation, which allocates the responsibility for examining an application for international protection lodged by a third-country national to the Member State which that national first entered or stayed in when entering EU territory. Thus, a Member State which has decided on humanitarian grounds to authorise the entry on its territory of a third-country national who does not have a visa and is not entitled to a waiver of a visa cannot be absolved of that responsibility. Against this background, the Court considers that the term 'irregular crossing of a border' also covers the situation in which a Member State admits into its terri-

\footnotetext{
30 In view of recital 19 and Article 27(1) of the Dublin III Regulation

31 Case C-63/15 Mehrdad Ghazelbash v. Staatssecretaris van Veiligheid en Justitie (2016) ECL I-409

32 The preamble to the Geneva Convention, op. cit., note 2., clearly states that all the obligations undertaken regard only signatory States, indicating that the asylum law may entail extremely burdensome obligations for certain countries and that a satisfying solution depends on international solidarity
} 
tory third-country nationals on humanitarian grounds, by way of derogation from the entry conditions generally imposed on third-country nationals. Furthermore, referring to the mechanisms laid down in the Dublin III Regulation, to Directive $2001 / 55^{33}$ and Article 78(3) of the TFEU, the Court finds that the fact that the border crossing occurred during the arrival of an exceptionally large number of third-country nationals seeking international protection is not a decisive factor. It also takes the view that the authorities of a first Member State tolerating the entry of those nationals who did not satisfy the entry conditions in principle required into their territory, due to exceptional circumstances of the crisis period, cannot be treated as a 'visa' situation. ${ }^{34}$ Consequently, the Court states that admitting third-country nationals into the territory of a Member State cannot be equated to the issuance of a visa, even in exceptional circumstances of a mass inflow of displaced persons into the EU.

\section{LEGAL IMPACT OF THE JUDGMENTS - CONSEQUENCES FOR THE REPUBLIC OF CROATIA}

The questions referred to the Court are in fact closely related to the functioning of the Dublin system in mass migration as well as to the issue of refugee rights. Therefore, the Court finds that the provisions of the Dublin III Regulation, as well as the conditions for entry laid down in the Schengen Borders Code, must inevitably apply, even in exceptional and crisis situations. Refugees are not migrants. As Hathaway and Foster ${ }^{35}$ find, recognition of the refugee status does not make a person a refugee but only declares him to be one, which means that he does not become a refugee because of recognition, but is recognised because he is a refugee. With these judgments the Court, once again, ignored the criticism of the doctrine. The Advocate General's opinion clearly states that the Dublin III Regulation does not include any mechanisms for controlling and managing mass migration and that the situation in the crisis period was exceptional, concluding that the non-functioning of the system was expected. On one hand, the Court decided on the temporary suspension of the Dublin system in Greece and Italy due to their difficult situations, whereas on the other, in these judgments it calls for the indispensable application of the Dublin system even in exceptional situations such as the mass inflow of migrants to the state border of a Member State. ${ }^{36}$ According to

\footnotetext{
33 Council Directive 2001/55 (EC) on minimum standards for giving temporary protection in the event of a mass influx of displaced persons and on measures promoting a balance of efforts between Member States in receiving such persons and bearing the consequences thereof (2001) OJ L 212

34 Within the meaning of Article 2(m) of the Dublin III Regulation, op. cit., note 1

35 Hathaway, C. J.; Foster, M., The Law of Refugee Status, Cambridge University Press, 2014, p. 1-16

36 See also: Goldirova, R., Greece under Fire over Refugee Treatment, EU Observes, 2008
} 
Bačić37, the system of responsibility-sharing under the Dublin III Regulation resulted in uneven burdens being imposed on EU Member States, with a particularly heavy burden being imposed on states on the southern and eastern borders due to the principle of responsibility allocated to the country of first entry into EU territory. Bačić also finds that the transfer of jurisdiction in asylum policies from national states to the EU has led to an uneven distribution of responsibilities and consequently to the non-functioning of the Dublin system as a whole and the questionable application of the Geneva Convention in general. ${ }^{38}$ Following the call by the German Chancellor directed at citizens of countries affected by wars, Croatia found itself in a very difficult situation. According to the official data reported by the Ministry of the Interior of the Republic of Croatia, $658068 \mathrm{mi}$ grants entered Croatia during the crisis period, out of which 558724 in 2015, usually at the borders of Eastern Croatia. Nearly all of them left Croatia on their way to Western Europe, while only 39 refugees applied for asylum. During the crisis period, the number of third-country nationals entering the country sometimes reached nearly 10,000 people a day. ${ }^{39}$ The 'laisser passer' policy applied by Croatia was the only possible solution at that moment given the fact that the country was, due to its economic situation and level of preparedness ${ }^{40}$, unable to receive such large numbers of third-country nationals and provide them with humane living conditions.$^{41}$ In her opinion, the Advocate General outlined the same argument as the one laid down by Article 31 of the Geneva Convention, which prohibits imposing penalties to refugees on account of their irregular entry. It is interesting to note that the Court refused to accept this connotation stating that the entry requirements laid down by the Schengen Borders code must inevitably apply and that, even in the case of fulfilling international obligations under the Geneva Convention, this obligation regards only the territory of the Member States of admission and not the territories of other Member States. This argument is valid given the fact that the Member States are signatories to the Geneva Con-

37 Bačić Selanec, N., Dublinska uredba i problem pograničnih država članica Europske unije, Prvih deset godina razvoja sustava azila u Hrvatskoj, in: Župarić-Iljić, D., (ed.). Zagreb: IMIN; Centar za mirovne studije; Kuća ljudskih prava, 2013, p. 2

38 See further: Bačić Selanec, N., Asylum Policy in Europe - the competences of the European Union and inefficiency of the Dublin system, Croatian Yearbook of European Law and Policy, vol. 8, No. 8, 2012, p. $41-76$

39 Data obtained through an interview with the Head of the Department for Irregular Migration of the Vukovar-Srijem County (the Croatian state border where families from the judgments crossed the border during the crisis period) conducted for the purpose of this paper, 11 February 2019

40 In the last 10 years, on average $30 \%$ of people in Croatia were at risk of falling into poverty or social exclusion, National Bureau of Statistics, Indicators of poverty and social exclusion, [https://www.dzs. hr/] Accessed 13 February 2019

41 Interview with the Head of the Department for Irregular Migration of the Vukovar-Srijem County, op. cit. 
vention, but the EU should not have ignored their international obligations under the Geneva Convention. According to Goodwin-Gill and Lambert, ${ }^{42}$ a transnational dialogue among courts can be an important instrument for the interpretation of the Geneva Convention even beyond the EU. Therefore, the Court has a central role in refugee protection in the EU and recognition of their refugee status and preventing the transformation of refugees into irregular migrants. According to Trauner ${ }^{43}$, the implementation of the existing EU asylum rules may overburden southern Member States while the perpetuated ignorance of these rules risks overburdening the northern Member States, which proves the inefficiency of this system in crisis situations. In a number of cases, the ECHR and the Court found that the Dublin system does not function and that it has certain legal inconsistencies, which triggered the reform of the system. This started with the Proposal for amending the Dublin III Regulation ${ }^{44}$, which introduced the so-called corrective allocation mechanism aimed at strengthening the principle of solidarity and fair responsibility-sharing. It becomes clear that, without a regulated system of solidarity among the Member States, there is no international solidarity, which makes this issue even wider. This judgment has failed to address all the difficulties encountered by the EU in the crisis period as well as the legal gaps of European legislation, indirectly confirming that the $\mathrm{EU}$, instead of protecting the rights of refugees to access a territory, puts the protection of the territory first. Disregarding the context in which these situations occurred, considering that the Dublin system is an adequate mechanism in emergency situations, such as the mass influx of migrants, and ignoring the international obligations of Member States will have a significant impact on the further development of the asylum system and fair responsibility-sharing among the Member States. In its judgments, the Court stressed that the term 'irregular entry' also covers a situation in which a Member State admits third-country nationals into its territory on humanitarian grounds and by way of derogation from entry conditions generally imposed on third-country nationals. According to Bačić and Goldner Lang, the lack of solidarity between the Member States called the whole Dublin system, as well as the full respect of human rights, into question. Even though the preamble to the Dublin III Regulation outlines the aim of striking a balance between the Member States in a spirit

42 See further: Goodwin-Gill, G. S.; Lambert, H. (eds.), The Limits of Transnational Law. Refugee Law, Policy Harmonization and Judicial Dialogue in the European Union, CUP, 2010

43 Trauner, F., Asylum policy: the EU's crises' and the looming policy regime failure, Journal of European Integration, vol. 38, Issue 3: EU Policies in Times of Crisis, 2016, p. 311-325, also: Hatton, T. J., European Asylum Policy. National Institute Economic Review, number 194, October 2005, pp, 106-119

44 Proposal for a Regulation of the European Parliament and of the Council establishing the criteria and mechanisms for determining the Member State responsible for examining an application for international protection lodged in one of the Member States by a third-country national or a stateless person (recast)COM/2016/0270 final/2 - 2016/0133 
of solidarity, it actually disregards the possibility of mass migratory pressure put on certain border Member States. This was precisely the situation Croatia found itself in during the crisis period, which was due to its geographical location. The effect of mass migration on border Member States has been highlighted with regard to Greece, where the Court noted that the country was unable to cope with the situation given the mass influx of refugees and migrants. ${ }^{45}$ As Mitsilegas finds, ${ }^{46}$ increased migratory pressure on a particular Member State results in focusing on the management of migration flows, rather than on the rights of the asylum seeker. Ultimately, this could give rise to viewing asylum seekers in negative light. The analysis of the provisions of the Proposal for amending the Dublin III Regulation shows an attempt to address the issue of solidarity between the Member States by introducing the so-called corrective allocation mechanism, which would be activated automatically as soon as a Member State is faced with a disproportionate burden. However, such an allocation mechanism only provides a current one-year basis of calculation, which would imply a provisional allocation of asylum applications, with a potential need to resettle the asylum seekers the following year. As Van Wolleghem finds ${ }^{47}$, this lack of flexibility likely maintains the burden on countries of entry, albeit for a limited amount of time. The author of this paper considers that the Court, in delivering its judgment, should have taken into account the fact that the situations concerned took place during an extremely large influx of migrants and refugees and that it should have determined Slovenia and Austria as the Member States responsible for examining the asylum applications lodged. If the border Member States were to be determined as responsible for considering all asylum applications during mass migration, they would face a real risk of not being able to handle such situations. This, in turn, would put the Member States in a situation in which they would not be able to comply with their obligations under the EU law and international law. The author also finds that a criterion for handling mass migration should be incorporated into the Proposal for amending the Dublin III Regulation in order to prepare the border Member States to implement such actions in a timely manner and harmonise their actions in these situations.

\footnotetext{
45 See Joined Cases C-411/10 and C-493/10, N. S. and M. E., judgment of 21 December 2011, paragraph 90

46 Mitsilegas, V., Solidarity and Trust in the Common European Asylum System, Comparative Migration Studies, vol. 2, No. 2, Amsterdam University Press, 2014

47 See further: Georges Van Wolleghem, P., If Dublin IV were in place during the refugee crisis...A simulation of the effect of mandatory relocation, Paper ISMU, Fondazione, Milano, 2018
} 


\section{CONCLUSION}

After analysing the legal framework, the judgments and the opinion of the Advocate General in cases A.S. v. Slovenia and Jafari v. Bundesamt für Fremdenwesen und Asyl, it becomes clear that the EU requires compliance with its acquis and the provisions thereof even in exceptional circumstances such as the mass inflow of migrants to the borders of a Member State. Therefore, allowing refugees to travel through Croatian territory without meeting the entry conditions laid down by the Schengen Borders Code and under Article 31 of the Geneva Convention shall be valid only for the entry into Croatian territory. Any further transfer of thirdcountry nationals to other Member States of the EU, even with the authorisation and facilitation of the Croatian authorities, must be considered irregular and such authorisation cannot be equal to visa issuance. Accordingly, the Court decided that Croatia is responsible for examining applications for international protection in cases A.S. v. Slovenia and Jafari v. Bundesamt für Fremdenwesen und Asyl. The opinion of the Advocate General was completely different from the ruling of the Court. In her opinion, the Advocate General outlines a number of arguments explaining why Croatia is not the Member State responsible for examining applications for international protection in the aforementioned cases, but the Court did not take those arguments into consideration and delivered a completely different judgment. Such judgments have significant moral and ethical implications for Croatia. Following these judgments, Croatia is indirectly held liable for facilitating irregular migration. These judgments are a result of the non-functioning of the Dublin system, imposing a burden on Croatia, a collateral victim of the system's inconsistencies. By building wire fences on their state borders, EU Member States such as Hungary and Slovenia left it entirely up to Croatia, a less economically developed country, to handle the mass inflow of refugees. The Dublin system is not a mechanism for controlling mass migration. Its provisions insist on an individual approach, while the crisis period and the problems that emerged during the crisis find themselves in a legal vacuum created by the system. The application of the Geneva Convention justifies the entry of third-country nationals into the territory of a signatory State if those persons are categorized as refugees. Why is the Court insisting on the application of the procedural rules of the EU asylum system even in situations of a mass influx of refugees arriving at the external borders of the EU and thus ignoring international obligations of the Member States? Will the Dublin system survive and manage to cope with what is today a migration crisis? Will the consequences of these judgments contribute to this and will the border Member States manage to handle the heavy burden imposed on them due to their geographical location? Obviously, more time is needed to answer all of these questions. 


\section{REFERENCES}

\section{BOOKS AND ARTICLES}

1. Bačić Selanec, N., Asylum Policy in Europe - the competences of the European Union and inefficiency of the Dublin system, Croatian Yearbook of European Law and Policy, vol. 8, No. 8, 2012

2. Bačić Selanec, N., Dublinska uredba i problem pograničnih država članica Europske unije, Prvih deset godina razvoja sustava azila u Hrvatskoj, in: Župarić-Iljić, D. (ed.) Zagreb: IMIN; Centar za mirovne studije; Kuća ljudskih prava, 2013

3. Georges Van Wolleghem, P.; If Dublin IV were in place during the refugee crisis...A simulation of the effect of mandatory relocation, Paper ISMU, Fondazione, Milano, 2018

4. Goldirova, R., Greece under Fire over Refugee Treatment, EU Observes, 2008

5. Goldner Lang, I.: Ima li solidarnosti u azilu i migracijama u Europskoj uniji? Prvih deset godina razvoja sustava azila u Hrvatskoj, in: Župarić-Iljić, D. (ed.), Zagreb: Institut za migracije i narodnosti: Centar za mirovne studije: Kuća ljudskih prava 2013

6. Goldner Lang, I.: The European Union and Migration: An Interplay of National, Regional, and International Law, American journal of international law, vol. 111, 2017

7. Goodwin-Gill, G. S.; Lambert, H. (eds.), The Limits of Transnational Law. Refugee Law, Policy Harmonization and Judicial Dialogue in the European Union, CUP, 2010

8. Hailbronner/Thym, Legal Framework for Entry and Border Control, in Hailbronner K.; Thym, D. (eds.), EU Immigration and Asylum Law, A Commentary, 2nd edition, C.H.Beck/Hart/ Nomos, 2016

9. Hathaway, C. J.; Foster, M., The Law of Refugee Status, Cambridge University Press, 2014

10. Hathaway, C., J., The evolution of the refugee rights regime, Cambridge University Press, 2005

11. Hatton, T. J.; European Asylum Policy, National Institute Economic Review, vol. 194, 2005

12. Lalić, G., Razvoj zajedničkog europskog sustava azila, Hrvatska i komparativna javna uprava: časopis za teoriju i praksu javne uprave, vol. 7 No. 4, 2007

13. Lambert H., Article 3 of the European Convention on Human Rights and the Protection of Refugees and Rejected Asylum Seekers against Refoulement from Europe, European Convention on Human Rights and Protection of Persons in Need of International Protection, Chisinau, 2000

14. Mitsilegas, V.; Solidarity and Trust in the Common European Asylum System, Comparative Migration Studies, vol. 2, No. 2, Amsterdam University Press, 2014

15. Schuster, L., Turning refugees into 'illegal migrants': Afghan asylum seekers in Europe, Ethnic and Racial Studies, vol. 34, - Issue 8: Irregular Migrants: Policy, Politics, Motives and Everyday Lives, 2011

16. Trauner, F., Asylum policy: the EU's crises' and the looming policy regime failure, Journal of European Integration, vol. 38, Issue 3: EU Policies in Times of Crisis, 2016

17. Weissbrodt, D., The Human Rights of Non-citizens, (OUP 2008); and Mantouvalou, R., The Labour and Social Rights of Migrants in International Law, in: Rubio-Marin (ed.), Human Rights, 2014 
18. Župan, M., The best interest of the child - a guiding principle in administering cross-border child related matters?, The United Nations Convention on the Rights of the Child. Taking Stock after 25 Years and Looking Ahead, Liefaard, Ton, Sloth-Nielsen Julia (ed.). Leiden: Brill | Nijhoff, 2017

\section{COURT OF JUSTICE OF THE EUROPEAN UNION}

1. Case C-490/16 A. S. vs. Republic of Slovenia (2017) ECL I-585

2. Case C-63/15 Mehrdad Ghazelbash v. Staatssecretaris van Veiligheid en Justitie (2016) ECL I-409

3. Case C-646/16 Khadija Jafari and Zainab Jafari v. Bundesamt fur Fremdenwesen und Asyl(2017) ECL I- 586

4. Cases C-411/10 and C-493/10 N. S. v. Secretary of State for the Home Department et. M. E. and Others v. Refugee Applications Commissioner and Minister for Justice, Equality and Law Reform (2011.) ECL I- 865

5. Opinion of Advocate General in cases C-490/16 and C-646/16 A.S. v. Republic of Slovenia and Jafari v. Bundesamt für Fremdenwesen und Asyl., 8 June 2017.

\section{ECHR}

1. M.S.S. vs. Belgium and Greece(2011) 53 EHRR 2

2. Saadi vs. Italy (2008) 49 EHRR 30

3. Ti vs. United Kingdom (2000) ECHR 705

4. Soering vs. United Kingdom (1989) ECHR 14

\section{EU LAW}

1. Charter of Fundamental Rights of the European Union (2007) OJ C 303

2. Consolidated versions of the Treaty on European Union and the Treaty on the Functioning of the European Union Consolidated version of the Treaty on European Union Consolidated version of the Treaty on the Functioning of the European Union Protocols Annexes to the Treaty on the Functioning of the European Union Declarations annexed to the Final Act of the Intergovernmental Conference which adopted the Treaty of Lisbon (2007) OJ C 202

3. Convention for the Protection of Human Rights and Fundamental Freedoms, Narodne novine (Official Gazette) - International treaties, No. 18/97, 6/99 - consolidated text, 8/99 - corr., 14/02, as amended by Protocol 14 to the Convention (2010) Narodne novine - International treaties, No. 1/06.

4. Convention Relating to the Status of Refugees, 25 July 1951.as amended by the 1967 Protocol Relating to the Status of Refugees, 31 January 1967.

5. Council Directive 2001/55 (EC) on minimum standards for giving temporary protection in the event of a mass influx of displaced persons and on measures promoting a balance of efforts between Member States in receiving such persons and bearing the consequences thereof (2001) OJ L 212 
6. Directive 2008/115 (EC) of the European Parliament and of the Council on common standards and procedures in Member States for returning illegally staying third-country nationals (2008) OJ L 348

7. Directive 2013/32 (EU) of the European Parliament and of the Council on common procedures for granting and withdrawing international protection (2013) OJ L 180

8. Proposal for a Regulation of the European Parliament and of the Council establishing the criteria and mechanisms for determining the Member State responsible for examining an application for international protection lodged in one of the Member States by a third-country national or a stateless person (recast) COM/2016/0270 final/2 - 2016/0133 (COD)

9. Regulation (EC) No 562/2006 of the European Parliament and of the Council establishing a Community Code on the rules governing the movement of person across borders (2006) OJ L 105/1

10. Regulation (EU) No 603/2013 of the European Parliament and of the Council on the establishment of Eurodac for the comparison of fingerprints for the effective application of Regulation (EU) No 604/2013 establishing the criteria and mechanisms for determining the Member State responsible for examining an application for international protection lodged in one of the Member States by a third-country national or a stateless person and on requests for the comparison with Eurodac data by Member States' law enforcement authorities and Europol for law enforcement purposes, and amending Regulation (EU) No 1077/2011 establishing a European Agency for the operational management of large-scale IT systems in the area of freedom, security and justice (2013) SL L180

11. Regulation No 604/2013 (EU) of the European Parliament and of the Council establishing the criteria and mechanisms for determining the Member State responsible for examining an application for international protection lodged in one of the Member States by a thirdcountry national or a stateless person (2013) OJ L180

\section{WEBSITE REFERENCES}

1. National Bureau of Statistics, Indicators of poverty and social exclusion, [https://www.dzs.hr/] Accessed 13 February 2019. 